\title{
PENGARUH KUALITAS LAYANAN TERHADAP KEPUASAN, KEPERCAYAAN DAN LOYALITAS PELANGGAN TRAVEL AGENT DI KABUPATEN BADUNG
}

\author{
Ni Luh Indiani \\ Fakultas Ekonomi UniversitasMahendradatta \\ Jl. Ken Arok No.12, Peguyangan Denpasar Utara, Bali 80115 \\ Email: luhindiani99@gmail.com
}

\begin{abstract}
Abstrak
Perkembangan teknologi yang semakin maju memiliki pengaruh penting dalam industri jasa pariwisata, yaitu pemanfaatan teknologi internet dalam proses pemesanan perjalanan wisata melalui travel agent online. Travel agent konvensional semakin ditinggalkan karena wisatawan beralih kepada travel agent online. Dalam kondisi ini travel agent konvensional perlu melakukan sejumlah upaya untuk mempertahankan pelanggan sehingga dapat bertahan. Penelitian ini bertujuan menganalisis pengaruh kualitas layanan terhadap kepuasan, kepercayaan dan loyalitas pelanggan travel agent di Kabupaten Badung. Responden penelitian adalah pelanggan domestik dan mancanegara yang menggunakan jasa travel agent di Kabupaten Badung, sebanyak 70 responden. Pengumpulan data dilakukan melalui survey menggunakan kuesioner. Pengujian hipotesis penelitian mempergunakan Partial Least Square (PLS). Hasil penelitian menunjukkan bahwa 1) kualitas layanan berpengaruh positif dan signifikan terhadap kepuasan, kepercayaan dan loyalitas pelanggan, 2) kepuasan pelanggan berpengaruh positif dan tidak signifikan terhadap loyalitas pelanggan, 3) kepercayaan pelanggan berpengaruh negatif dan tidak signifikan terhadap loyalitas pelanggan, 4) kepuasan dan kepercayaan pelanggan tidak memediasi pengaruh kualitas layanan terhadap loyalitas pelanggan.Travel agent di Kabupaten Badung seharusnya meningkatkan dan memperhatikan indikator-indikator pendukung kepuasan, kepercayaan dan loyalitas pelanggan sehingga pelanggan tidak mudah beralih ke pesaing

Kata kunci : kualitas layanan, kepuasan pelanggan, kepercayaan pelanggan dan loyalitas pelanggan
\end{abstract}

\begin{abstract}
The development of increasingly advanced technology has an important influence in the tourism service industry, namely the utilization of internet technology in the process of booking tour and travels through online travel agents. Conventional travel agents are increasingly being abandoned as travelers turn to online travel agents. Under these conditions conventional travel agents need to make a number of efforts to keep customers in order to survive. This study aims to analyze the effect of service quality on satisfaction, trust and loyalty of travel agent customers in Badung regency. Research respondents are domestic and foreign customers who use travel agent services in Badung regency, as many as 70 respondents. Data collection was done through survey using questionnaire. Testing research
\end{abstract}


hypothesis using Partial Least Square (PLS).The result of the research shows that 1) the quality of service has positive and significant effect to customer satisfaction, trust and loyalty, 2) customer satisfaction has positive and insignificant effect to customer loyalty, 3) customer trust has negative and insignificant effect to customer loyalty, 4) satisfaction and customer trust does not mediate the influence of service quality on customer loyalty.Travel agent in Badung regency should improve and pay attention to the indicators supporting the satisfaction, trust and customer loyalty so that customers are not easy to switch to competitors.

Keywords: service quality, customer satisfaction, customer trust and customer loyalty

\section{A. PENDAhULUAN}

\section{Latar Belakang Masalah}

Perkembangan industri pariwisata di Indonesia yang terus meningkat diimbangi dengan perkembangan teknologi informasi yang semakin maju. Hal tersebut memiliki pengaruh penting dalam industri jasa pariwisata, salah satunya adalah pemanfaatan teknologi internet dalam proses pemesanan perjalanan wisata melalui travel agent online atau sering dikenal dengan OTA (online travel agent). OTA mendapat respon yang sangat baik dari wisatawan di Indonesia, dimana setiap tahun penggunaan OTA semakin meningkat, yang ditandai dengan jumlah penjualan travel online mengalami peningkatan setiap tahunnya.Bali merupakan salah satu destinasi wisata di Indonesia yang terkenal di seluruh dunia. Keunikan yang dimiliki oleh Bali seperti seni budaya, adat istiadat, agama, dan obyek wisata menjadi daya tarik tersendiri bagi wisatawan untuk berkunjung.Rata-rata pertumbuhan kunjungan wisatawan mancanegara ke Bali khususnya di kabupaten
Badung lebih rendah dibandingkan rata-rata pertumbuhan penjualan travel online. Hal ini menunjukkan bahwa travel online semakin digemari oleh wisatawan dan travel agent konvensional di kabupaten Badung semakin ditinggalkan.Untuk itu, penelitian ini bertujuan mengkaji faktor apa yang mampu meningkatkan loyalitas wisatawan terhadap travel agent konvensional. Hasil penelitian diharapkan dapat memberikan rekomendasi bagi travel agent konvensional untuk mampu bertahan ditengah gempuran travel agent online yang mayoritas dimiliki asing dengan nilai kapital yang besar.

\section{Landasan Teori}

Loyalitas pelanggan merupakan hal yang sangat penting bagi perusahaan, karena dengan memiliki pelanggan yang loyal maka perusahaan akan bisa bertahan dan memenangkan persaingan dalam berbisnis.Pelanggan akan loyal pada suatu layanan jasa apabila mereka merasakan kepuasan terhadap layanan yang diterima (Ismail, 2014).Kepuasan pelanggan akan mendorong terciptanya loyalitas 
pelanggan, dimana pelanggan yang loyal umumnya akan merekomendasikan travel agent kepada teman dan rekannya serta akan terus menggunakan travel agent yang sama kedepannya. Kepuasan pelanggan menjadi prioritas bagi perusahaan karena akan membentuk loyalitas pelanggan.Hal ini dikonfirmasi studi oleh Verma dan Singh (2017), Lai dan Nguyen (2017) serta Wendha et al. (2013).

Peningkatan loyalitas pelanggan tidak hanya ditentukan oleh kepuasan pelanggan, namun loyalitas pelanggan juga dipengaruhi kepercayaan pelanggan terhadap perusahaan. Pelanggan percaya terhadap suatu perusahaan karena memiliki keyakinan akan keahlian perusahaan tersebut untuk dapat melayani secara baik (Laely, 2016). Pelanggan akan mempunyai keterikatan batin terhadap perusahaan atau penyedia jasa karena tumbuh kepercayaan pelanggan terhadap layanan yang digunakan. Kepercayaan pelanggan sangat penting untuk melestarikan hubungan dan membangun kembali kesetiaan kepada penyedia layanan, sehingga kepercayaan pelanggan akan meningkatkan loyalitas pelanggan (Sutrisno et al.,2016,Soegoto,2013 dan Andleeb, 2017).

Loyalitas pelanggan sangat penting bagi sektor bisnis manapun termasuk industri jasa travel agent, karena pelanggan yang loyal akan memiliki sifat positif terhadap perusahaan. Pelanggan bersikap positif apabila tingkat layanan yang diterima (perceived service) sesuai bahkan melebihi dengan tingkat layanan yang diharapkan (expected service). Oleh karena itu, perusahaan harus mampu memberikan layanan yang berkualitas tinggi dan sesuai dengan kebutuhan pelanggan sehingga pelanggan tidak akan mudah beralih ke pesaing. Dengan semakin meningkatkan kualitas layanan, maka loyalitas pelanggan akan semakin meningkat. Hal ini dikonfirmasi studi oleh Chodzaza dan Gombachika (2013) dan Osarenkhoe et al. (2017). Kualitas layanan pada industri jasa harus mendapat perhatian khusus karena usaha jasa yang dominan menawarkan aspek layanan, sehingga kualitas layanan yang diberikan sesuai dengan harapan pelanggan yang akan berdampak dalam meningkatkan loyalitas pelanggan. Pernyataan ini sesuai dengan hasil penelitian Hussein dan Hapsari (2015) dan Sumertana (2016) bahwa kualitas layanan berpengaruh signifikan terhadap loyalitas pelanggan.

Pelayanan yang sesuai dengan kebutuhan, keinginan dan harapan, akan berpengaruh pada persepsi pelanggan terhadap jasa tersebut sehingga berdampak pada kepuasan pelanggan. Pihak penyedia jasa harus mampu memberikan kualitas layanan yang optimal sehingga dapat meningkatkan kepuasan pelanggan (Rifai et al.,2016). Kualitas layanan pada industri jasa merupakan faktor yang berperanan penting dalam meningkatkan kepuasan pelanggan. Hal ini dikonfirmasi studi oleh Indiani et al. (2016), Ilyas et al. (2016) dan Chotivanich (2014) yang menemukan bahwa kualitas layanan 
berpengaruh signifikan terhadap kepuasan pelanggan.

Penilaian pelanggan terhadap kualitas layanan akan mempengaruhi tingkat kepercayaan pelanggan. Semakin baik kualitas layanan yang diberikan kepada pelanggan maka semakin tinggi pula kepercayaan pelanggan dalam menggunakan produk atau jasa yang ditawarkan perusahaan (Darwin dan Kunto, 2014).Kepercayaan pelanggan terbangun ketika pihak penyedia jasa dapat memenuhi kebutuhan pelanggan dan sesuai dengan yang diharapkan. Dengan demikian kualitas layanan harus mendapat perhatian khusus dari perusahaan sehingga dapat memberikan layanan yang maksimal kepada pelanggan yang akan berdampak meningkatkan kepercayaan pelanggan (Rat et al.,2015, Kartikasari et al.,2014, dan Setyaningsih,2014).Berdasarkan pemaparan tersebut, penelitian ini menganalisis faktor yang mampu meningkatkan loyalitas wisatawan terhadap travel agent konvensional di Bali sehingga travel agent konvensional mampu bertahan ditengah persaingan industri jasa pariwisata yang semakin kompleks.

\section{Rumusan Masalah}

Pokok permasalahan dalam penelitian ini dapat dirumuskan sebagai berikut:

1. Bagaimanakah pengaruh kualitas layanan terhadap kepuasan pelanggan pada travel agent di kabupaten Badung?

2. Bagaimanakah pengaruh kualitas layanan terhadap kepercayaan pelanggan pada travel agent di kabupaten Badung?
3. Bagaimanakah pengaruh kepuasan pelanggan terhadap loyalitas pelanggan pada travel agent di kabupaten Badung?

4. Bagaimanakah pengaruh kepercayaan pelanggan terhadap loyalitas pelangan pada travel agent di kabupaten Badung?

5. Bagaimanakah pengaruh kualitas layanan terhadap loyalitas pelanggan pada travel agent di Kabupaten Badung?

6. Bagaimanakah peran kepuasan pelanggan memediasi pengaruh kualitas layanan terhadap loyalitas pelanggan pada travel agent di kabupaten Badung?

7. Bagaimanakah peran kepercayaan pelanggan memediasi pengaruh kualitas layanan terhadap loyalitas pelanggan pada travel agent di kabupaten Badung?

\section{Tujuan Penelitian}

Sesuai dengan perumusan masalah diatas, maka tujuan dari penelitian ini sebagai berikut:

1. Menganalisis pengaruh kualitas layanan terhadap kepuasan pelanggan pada travel agent di kabupaten Badung.

2. Menganalisis pengaruh kualitas layanan terhadap kepercayaan pelanggan pada travel agent di kabupaten Badung.

3. Menganalisis pengaruh kepuasan pelanggan terhadap loyalitas pelanggan travel agent di kabupaten Badung.

4. Menganalisis pengaruh kepercayaan pelanggan terhadap loyalitas pelangan pada travel agent di kabupaten Badung. 
5. Menganalisis pengaruh kualitas layanan terhadap loyalitas pelanggan pada travel agent di kabupaten Badung.

6. Menganalisis peran kepuasan pelanggan dalam memediasi pengaruh kualitas layanan terhadap loyalitas pelanggan pada travel agent di kabupaten Badung.

7. Menganalisis peran kepercayaan pelanggan dalam memediasi pengaruh kualitas layanan terhadap loyalitas pelanggan pada travel agent di kabupaten Badung.

\section{Hipotesis Penelitian}

H1 :Kualitas layanan berpengaruh positif dan signifikan terhadap kepuasan pelanggan

$\mathrm{H} 2$ : Kualitas layanan berpengaruh positif dan signifikan terhadap kepercayaan pelanggan

H3 : Kepuasan pelanggan berpengaruh positif dan signifikan terhadap loyalitas pelanggan

H4 : Kepercayaan pelanggan berpengaruh positif dan signifikan terhadap loyalitas pelanggan

H5 : Kualitas layanan berpengaruh positif dan signifikan terhadap loyalitas pelanggan

H6 : Kepuasan pelanggan memediasi pengaruh kualitas layanan terhadap loyalitas pelanggan

H7 : Kepercayaan pelanggan memediasi pengaruh kualitas layanan terhadap loyalitas pelanggan

\section{B. METODE PENELITIAN}

Pengumpulan data pada penelitian ini dilakukan dengan survey menggunakan kuesioner yang dibagikan kepada pelanggan travel agent di kabupaten Badung. Populasi dalam penelitian ini adalah seluruh pelanggan travel agent di kabupaten Badung. Pengambilan sampel menggunakan

nonprobabilitysampling dengan teknik sampel purposive sampling method dan accidental method. Jumlah responden dalam penelitian ini adalah 70 responden. Variabel dalam penelitian ini terdiri dari variabel kualitas layanan sebagai variabel eksogen, variabel kepuasan, kepercayaan dan loyalitas pelanggan sebagai variabel endogen.

Analisa data dalam penelitian ini menggunakan analisis deskriptif dan analisis inferensial dengan teknik PLS (Partial Least Square).Langkahlangkah penggunaan PLS yaitu 1) evaluasi outer model, dilakukan melalui validitas isi (content validity), convergent validity dan discriminant validity dari indikator pembentuk konstruk laten serta indicator reliability, composite reliability dan cronbach alfa untuk blok indikatornya, 2)rancangan model struktural (inner model), 3) struktur diagram jalur, 4) konversi diagram ke sistem persamaan, 5) estimasi weight, koefesien jalur dan loading, 6) estimasi goodness of fit (gof),7) uji hipotesis (resampling bootstrapping).

\section{HASIL}

validitas,

Berdasarkan hasil uji menunjukkan seluruhindikator konstruk dinyatakan valid karena nilai korelasi lebih dari 0,3 dan signifikan pada 0,05 . Uji reliabilitas konstruk diukur dengan nilai Crombach's alpha, dimana seluruh konstruk yaitu X, Y1, Y2 dan 
Y3 reliabel, karena nilai Cronbach Alphabased on Standardized Items $>$ 0,60 (kriteria Nunnaly 1969).

Evaluasi Model Pengukuran

Hasil penelitian menunjukkan bahwa seluruh indikator dapat mengukur konstruknya secara signifikan, karena nilai t-statistik seluruh indikator lebih besar dari 1,96 . Nilai outer loading seluruh indikator lebih besar dari 0,6, yang berarti bahwa seluruh indikator

Tabel 1

Validitas Konstruk mengukur konstruk latennya dengan baik. Hasil penelitian menunjukkan nilai AVE masing-masing konstruk lebih besar dari 0,5, yang berarti bahwa seluruh konstruk dinyatakan valid. Hasil penelitian menunjukkan bahwa nilai CR lebih besar dari 0,7 , yang berarti bahwa seluruh konstruk dinyatakan reliabel.

\begin{tabular}{|c|c|c|c|c|c|c|c|}
\hline Konstruk & Indikator & Item & $\begin{array}{l}\text { Korela } \\
\text { si }\end{array}$ & $\begin{array}{c}\text { Nilai t- } \\
\text { statisti } \\
\mathbf{k} \\
\end{array}$ & $\begin{array}{c}\text { Nilai } \\
\text { Outer } \\
\text { Loading }\end{array}$ & AVE & $\mathbf{C R}$ \\
\hline \multirow{13}{*}{$\begin{array}{c}\text { Kualitas } \\
\text { Layanan } \\
\text { (X) }\end{array}$} & \multirow{2}{*}{$\begin{array}{l}\text { Tangible } \\
\text { (X.1) }\end{array}$} & Fasilitas fisik (X.1.1) & 0,494 & \multirow{2}{*}{6,15} & \multirow{2}{*}{0,74} & \multirow{13}{*}{0,81} & \multirow{13}{*}{0,93} \\
\hline & & Penampilan staf (X.1.2) & 0,642 & & & & \\
\hline & \multirow{3}{*}{$\begin{array}{l}\text { Reliability } \\
\text { (X.2) }\end{array}$} & Pelayanan yang akurat (X.2.1) & 0,646 & \multirow{3}{*}{16,32} & \multirow{3}{*}{0,82} & & \\
\hline & & Tidak ada kesalahan (X.2.2) & 0,617 & & & & \\
\hline & & Pelayanan tepat waktu (X.2.3) & 0,700 & & & & \\
\hline & \multirow{2}{*}{$\begin{array}{l}\text { Responsiv } \\
\text { eness } \\
\text { (X.3) }\end{array}$} & Membantu sesuai keperluan (X.3.1) & 0,672 & \multirow{2}{*}{23,95} & \multirow{2}{*}{0,85} & & \\
\hline & & Merespon dengan segera (X.3.2) & 0,679 & & & & \\
\hline & \multirow{3}{*}{$\begin{array}{c}\text { Assurance } \\
\text { (X.4) }\end{array}$} & Kesopanan dan keramahan (X.4.1) & 0,590 & \multirow{3}{*}{19,43} & \multirow{3}{*}{0,82} & & \\
\hline & & Pelayanan sesuai keahlian (X.4.2) & 0,544 & & & & \\
\hline & & Profesional dan jujur (X.4.3) & 0,618 & & & & \\
\hline & \multirow{3}{*}{$\begin{array}{l}\text { Empathy } \\
\text { (X.5) }\end{array}$} & Perhatian secara personal (X.5.1) & 0,658 & \multirow{3}{*}{23,30} & \multirow{3}{*}{0,87} & & \\
\hline & & Memahami kebutuhan pelanggan (X.5.2) & 0,678 & & & & \\
\hline & & Menyapa dengan nama (X.5.3) & 0,698 & & & & \\
\hline \multirow{3}{*}{$\begin{array}{l}\text { Kepuasan } \\
\text { Pelanggan } \\
\text { (Y1) }\end{array}$} & & Manfaat sesuai dengan biaya (Y1.1 ) & 0,776 & 7,42 & 0,68 & \multirow{3}{*}{0,58} & \multirow{3}{*}{0,80} \\
\hline & & Kepuasan terhadap pelayanan (Y1.2) & 0,691 & 14,44 & 0,75 & & \\
\hline & & Pengalaman sesuai harapan (Y1.3) & 0,803 & 27,35 & 0,84 & & \\
\hline \multirow{6}{*}{$\begin{array}{l}\text { Kepercaya } \\
\text { an } \\
\text { Pelanggan } \\
\text { (Y2) }\end{array}$} & \multirow{2}{*}{$\begin{array}{c}\text { Benevolen } \\
\text { ce (Y2.1) }\end{array}$} & Itikat baik menjalin hubungan (Y2.1.1 ) & 0,741 & \multirow{2}{*}{47,78} & \multirow{2}{*}{0,93} & \multirow{6}{*}{0,67} & \multirow{6}{*}{0,91} \\
\hline & & Keuntungan berlebih secara tidak jujur (Y2.1.2) & 0,749 & & & & \\
\hline & \multirow{2}{*}{$\begin{array}{l}\text { Honesty } \\
\text { (Y2.2) }\end{array}$} & Bertanggung jawab terhadap keluhan (Y2.2.1 ) & 0,610 & \multirow{2}{*}{30,80} & \multirow{2}{*}{0,90} & & \\
\hline & & Pelayanan sesuai yang dijanjikan (Y2.2.2) & 0,785 & & & & \\
\hline & \multirow{2}{*}{$\begin{array}{l}\text { Openness } \\
\text { (Y2.3) }\end{array}$} & Memberikan informasi yang dibutuhkan (Y2.3.1) & 0,695 & \multirow{2}{*}{22,09} & \multirow{2}{*}{0,87} & & \\
\hline & & Mendapat informasi yang diinginkan (Y2.3.2) & 0,701 & & & & \\
\hline
\end{tabular}




\begin{tabular}{|c|l|l|l|l|l|l|}
\hline \multirow{2}{*}{$\begin{array}{c}\text { Loyalitas } \\
\text { Pelanggan } \\
\text { (Y3) }\end{array}$} & Pilihan utama (Y3.1) & 0,875 & 25,87 & 0,87 & \\
\cline { 2 - 7 } & Retensi (Y3.2) & 0,790 & 16,44 & 0,80 & 0,69 & 0,87 \\
\cline { 2 - 7 } & Rekomendasi (Y3.3) & 0,823 & 18,84 & 0,82 & \\
\hline
\end{tabular}

Evaluasi Model Struktural

Tabel 2

Evaluasi Model Struktural

\begin{tabular}{|c|c|c|}
\hline Konstruk & R Square & Communality \\
\hline $\begin{array}{c}\text { Kepercayaan } \\
\text { Pelanggan }\end{array}$ & 0,75 & 0,81 \\
\hline $\begin{array}{c}\text { Kepuasan } \\
\text { Pelanggan }\end{array}$ & 0,43 & 0,58 \\
\hline $\begin{array}{c}\text { Kualitas } \\
\text { Layanan }\end{array}$ & & 0,67 \\
\hline $\begin{array}{c}\text { Loyalitas } \\
\text { Pelanggan }\end{array}$ & 0,47 & 0,69 \\
\hline Rata-Rata & 0,55 & 0,69 \\
\hline
\end{tabular}


Tabel 2 menunjukkan bahwa nilai $\mathrm{R}^{2}$ kepercayaan pelanggan sebesar 0,75, maka model tersebut termasuk kriteria kuat berdasarkan kriteria Chin (Lathan dan Ghozali, 2012:85), maknanya adalah variasi kualitas layanan mampu menjelaskan variasi kepercayaan pelanggan sebesar 75 persen, sisanya 25 persen dijelaskan oleh variasi variabel lain. Kepuasan pelanggan memiliki nilai $R$-square sebesar 0,43 atau termasuk model mendekati kuat, artinya variasi kualitas layanan mampu menjelaskan variasi kepuasan pelanggan yaitu sebesar 43 persen sisanya 57 persen dijelaskan oleh variasi diluar model. Sedangkan nilai $\mathrm{R}^{2}$ loyalitas pelanggan sebesar 0,47 atau termasuk kriteria model mendekati kuat, maknanya adalah variasi kualitas layanan, kepuasan pelanggan dan kepercayaan pelanggan mampu menjelaskan variasi loyalitas pelanggan sebesar 47 persen, sedangkan 53 persen lainnya dijelaskan oleh variasi konstruk lain yang tidak masuk dalam model.
Nilai $Q$-Square Predictive Relevanceadalah 0,92 , yang berarti bahwa model hasil estimasi adalah termasuk dalam kriteria kuat, artinya 92 persen variasi konstruk endogen dapat diprediksi oleh variasi konstruk eksogen. Hasil perhitungan Goodness of Fit $(G o F)$ menunjukkan nilai sebesar $\sqrt{\mathrm{AR}^{2}} *$ A.Com $=\sqrt{ } 0,55 * 0,69=$ 0,62 Artinya model global adalah prediktif yang bagus (large). Dalam pengujian hipotesis, Ho ditolak atau nilai sig $<0,05$ (atau nilai $\mathrm{t}$ statistik> 1,96 dengan level signifikan 0,05).

Tabel 3

Path Analisis dan Pengujian Statistik

\begin{tabular}{|c|c|c|c|c|c|c|}
\hline KONSTRUK & $\begin{array}{l}\text { Original } \\
\text { Sample } \\
(\mathbf{O})\end{array}$ & $\begin{array}{l}\text { Sample } \\
\text { Mean } \\
\text { (M) }\end{array}$ & $\begin{array}{l}\text { Standard } \\
\text { Deviation } \\
\text { (STDEV) }\end{array}$ & $\begin{array}{l}\text { Standard } \\
\text { Error } \\
\text { (STERR) }\end{array}$ & $\begin{array}{c}\text { T Statistics } \\
\text { (|O/STERR|) }\end{array}$ & Keterangan \\
\hline $\begin{array}{l}\text { KUALITAS LAYANAN -> } \\
\text { KEPUASAN PELANGGAN }\end{array}$ & 0,65 & 0,66 & 0,09 & 0,09 & 7,60 & Signifikan \\
\hline $\begin{array}{c}\text { KUALITAS LAYANAN -> } \\
\text { KEPERCAYAAN } \\
\text { PELANGGAN }\end{array}$ & 0,87 & 0,87 & 0,03 & 0,03 & 27,44 & Signifikan \\
\hline $\begin{array}{l}\text { KEPUASAN PELANGGAN -> } \\
\text { LOYALITAS PELANGGAN }\end{array}$ & 0,11 & 0,10 & 0,13 & 0,13 & 0,86 & $\begin{array}{l}\text { Tidak } \\
\text { Signifikan }\end{array}$ \\
\hline
\end{tabular}


Jurnal Satyagraha, Vol. 02, No. 02, Agustus 2019 - Januari 2020 ISSN :2620-6358

\begin{tabular}{|c|c|c|c|c|c|c|}
\hline $\begin{array}{c}\text { KEPERCAYAAN } \\
\text { PELANGGAN -> LOYALITAS } \\
\text { PELANGGAN }\end{array}$ & $-0,15$ & $-0,16$ & 0,19 & 0,19 & 0,81 & $\begin{array}{c}\text { Tidak } \\
\text { Signifikan }\end{array}$ \\
\hline $\begin{array}{c}\text { KUALITAS LAYANAN -> } \\
\text { LOYALITAS PELANGGAN }\end{array}$ & 0,74 & 0,75 & 0,18 & 0,18 & 4,16 & Signifikan \\
\hline
\end{tabular}


Jurnal Satyagraha, Vol. 02, No. 02, Agustus 2019 - Januari 2020 ISSN :2620-6358

Pengujian mediasi dianalisis menggunakan metode pemeriksaan melalui analisis direct dan indirect effect. Hasil pengujian menunjukkan bahwa kepuasan dan kepercayaan pelanggan bukan merupakan mediasi antara kualitas layanan terhadap loyalitas pelanggan, karena koefisien hubungan tidak langsung dari kepuasan dan kepercayaan pelanggan terhadap loyalitas pelanggan tidak signifikansedangkan koefisien hubungan langsungnyaadalah signifikan.

\section{PEMBAHASAN}

\section{Pengaruh Kualitas Layanan Terhadap Kepuasan Pelanggan}

Hasil penelitian menunjukkan bahwa kualitas layanan berpengaruh positif dan signifikan terhadap kepuasan pelanggan. Hal ini berarti bahwa semakin baik kualitas layanan yang diberikan oleh travel agent di kabuapten Badung maka akan dapat meningkatkan kepuasan pelanggan dan begitu juga sebaliknya. Kualitas layanan pada industri jasa travel agent merupakan faktor yang signifikan dalam meningkatkan kepuasan, karena travel agent memiliki karakteristik usaha yang dominan menawarkan jasa layanan. Melihat dari kararakteristik responden dimana mayoritas responden memiliki pendidikan sarjana, dengan tingkat pendidikan yang tinggi mereka lebih mampu menilai kualitas layanan secara lebih baik dan komprehensif dan menjadi faktor yang menentukan kepuasan terhadap layanan. Responden menilai kualitas layanan berdasarkan pada dimensinya yaitu fasilitas fisik, penampilan karyawan, layanan yang akurat dan sesuai yang dijanjikan, tepat waktu, tidak melakukan kesalahan dalam pelayanan, segera merespon keluhan pelanggan, kesopanan dan keramahan serta memberikan perhatian secara personal kepada pelanggan.

\section{Pengaruh Kualitas Layanan Terhadap Kepercayaan Pelanggan}

Hasil penelitian menunjukkan bahwa kualitas layanan berpengaruh positif dan signifikan terhadap kepercayaan pelanggan. Ini berarti bahwa dengan menawarkan layanan yang semakin berkualitas, maka semakin tinggi pula kepercayaan pelanggan kepada travel agent di kabuapten Badung. Upaya perusahaan untuk menciptakan kualitas layanan yang baik bertujuan untuk membentuk hubungan antar pelanggan dengan perusahaan dan menumbuhkan kepercayaan pelanggan terhadap perusahaan. Melihat karakteristik usaha travel agent yang dominan menawarkan jasa dibandingkan barang berwujud, sehingga usaha jasa travel agent lebih banyak menawarkan aspek layanan. Dengan demikian untuk mewujudkan kepercayaan pelanggan, usaha travel agent sangat bergantung pada aspek layanan.

Pengaruh Kepuasan Pelanggan Terhadap Loyalitas Pelanggan

Hasil penelitian menunjukkan bahwamenunjukkan bahwa kepuasan pelanggan berpengaruh positif dan tidak signifikan terhadap loyalitas pelanggan. Hal ini berarti kepuasan pelanggan tidak begitu mempengaruhi loyalitas pelanggan. Walaupun pelanggan merasa kurang puas terhadap layanan yang diberikan, tetapi mereka tetap loyal untuk menggunakan 
Jurnal Satyagraha, Vol. 02, No. 02, Agustus 2019 - Januari 2020 ISSN :2620-6358

layanan jasa travel agent di kabupaten Badung. Hal ini disebabkan karena untuk beralih ke perusahaan jasa lainnya menimbulkan biaya berpindah (switching cost) yang cukup tinggi. Switching cost yang timbul meliputi waktu dan biaya psikologis dalam menghadapi ketidakpastian pada perusahaan jasa yang baru, karena melihat karakteristik jasa yang sifatnya tidak berwujud sehingga memerlukan cukup waktu dan biaya dalam memilih perusahaan jasa baru yang tepat.

\section{Pengaruh Kepercayaan Pelanggan Terhadap Loyalitas Pelanggan}

Hasil penelitian menunjukkan bahwa kepercayaan pelanggan berpengaruh negatif dan tidak signifikan terhadap loyalitas pelanggan. Hal ini berarti bahwa loyalitas pelanggan tidak dipengaruhi oleh kepercayaan pelanggan.Kurangnya kepercayaan pelanggan tidak mempengaruhi loyalitas pelanggan terhadap travel agent di kabupaten Badung. Pelanggan tetap setia menggunakan travel agent yang sama walaupun tingkat kepercayaan pelanggan rendah. Hal ini disebabkan karena travel agent memiliki karakteristik usaha yang bersifat intangible (tidak berwujud), sehingga untuk berpindah ke perusahaan jasa travel agent yang baru menimbulkan biaya berpindah (switching cost) yang cukup tinggi. Biaya tidak hanya berupa biaya materiil, namun juga biaya non materiil, seperti upaya dan waktu yang harus dikeluarkan untuk mempelajari sistem layanan baru, upaya dan waktu untuk membangun komunikasi yang baik dengan staf travel agent yang baru, dan beradaptasi dengan setiap perbedaan antara travel agent terdahulu dan travel agent yang baru.

\section{Pengaruh Kualitas Layanan Terhadap Loyalitas Pelanggan}

Hasil penelitian menunjukkan bahwa kualitas layanan berpengaruh positif dan signifikan terhadap loyalitas pelanggan. Hal ini berarti semakin baik kualitas layanan yang diberikan maka loyalitas pelanggan semakin meningkat. Ketika pertama kali pelanggan mendapatkan kualitas layanan yang baik dari travel agent, maka mereka akan menggunakan kembali jasa travel agent kedepannya dan mengharapkan layanan yang lebih baik lagi pada transaksi berikutnya. Kualitas layanan pada industri jasa merupakan faktor yang signifikan dalam mempengaruhi loyalitas pelanggan, karena melihat karakteristik usaha travel agent yang dominan menawarkan aspek layanan. Oleh karena itu, untuk menciptakan loyalitas pelanggan, industri jasa travel agent harus mampu memberikan layanan prima (excellent service) kepada pelanggan.

\section{Peran Kepuasan Pelanggan Dalam}

Memediasi Pengaruh Kualitas Layanan Terhadap Loyalitas Pelanggan

Berdasarkan hasil analisis direct dan indirect effect dengan menggunakan metode pemeriksaaan, maka dinyatakan kepuasan pelanggan bukan merupakan mediasi antara kualitas layanan terhadap loyalitas pelanggan karena hubungan kepuasan pelanggan dengan loyalitas pelanggan tidak signifikan sedangkan hubungan langsung antara kualitas layanan dengan loyalitas pelanggan adalah signifikan. Hal ini menunjukkan bahwa kepuasan pelanggan tidak mampu 
Jurnal Satyagraha, Vol. 02, No. 02, Agustus 2019 - Januari 2020 ISSN :2620-6358

menjelaskan pengaruh kualitas layanan terhadap loyalitas pelanggan.

Peran Kepercayaan Pelanggan Dalam Memediasi Pengaruh Kualitas Layanan Terhadap Loyalitas Pelanggan

Berdasarkan hasil analisis direct dan indirect effect dengan menggunakan metode pemeriksaaan, bahwa kepercayaan pelanggan bukan merupakan mediasi antara kualitas layanan terhadap loyalitas pelanggan karena hubungan kepercayaan pelanggan dengan loyalitas pelanggan tidak signifikan sedangkan hubungan langsung antara kualitas layanan dengan loyalitas pelanggan adalah signifikan. Hal ini berarti kepercayaan pelanggan tidak mampu menjelaskan pengaruh kualitas layanan terhadap loyalitas pelanggan.

\section{E. Implikasi Penelitian}

Temuan dari penelitian ini adalah kualitas layanan berpengaruh positif dan signifikan terhadap kepuasan, kepercayaan dan loyalitas pelanggan. Oleh karena itu, maka implikasi manajerial dalam pengelolaan travel agent di kabupaten Badung adalah agar kualitas layanan semakin baik, travel agent perlu meningkatkannya pada sejumlah indikatornya yaitu memberikan perhatian secara personal kepada pelanggan, memahami kebutuhan pelanggan, menyapa pelanggan dengan menyebut namanya, bersedia membantu sesuai keperluan pelanggan, merespon permintaan dengan segera, pelayanan yang akurat, meminimalisir kesalahan, layanan tepat waktu sesuai dengan yang dijanjikan, kesopanan dan keramahan, memberikan layanan sesuai keahlian dan bersikap professional dalam memberikan layanan. Aspek - aspek ini penting untuk semakin ditingkatkan melalui pendidikan dan pelatihan secara berkelanjutan dan memberikan motivasi baik material (insentif, gaji, bonus) maupun nonmaterial (penghargaan, promosi) sehingga kinerja karyawan semakin meningkat.Untuk semakin meningkatkan kepuasan pelanggan, travel agent perlu memastikan indikatorindikatornya yang terdiri dari pengalaman menggunakan travel agent sesuai dengan harapan, kepuasan terhadap layanan dan kesesuaian manfaat dengan biaya yang dikeluarkan. Indikator tersebut perlu dievaluasi secara teratur untuk memastikan kepuasan pelanggan semakin meningkat. Kepercayaan pelanggan dapat dibentuk melalui pemenuhan indikator-indikator berikut: itikad baik dalam menjalin hubungan, bertindak jujur, bertanggung jawab menangani keluhan, layanan sesuai yang dijanjikan, memberikan informasi yang dibutuhkan pelanggan dan pelanggan mendapatkan informasi penting yang diinginkan.

\section{F. KESIMPULAN}

Kualitas layanan berpengaruh positif dan signifikan terhadap kepuasan, kepercayaan dan loyalitas pelanggan.Kepuasan pelanggan berpengaruh positif dan tidak signifikan terhadap loyalitas pelanggan, yang berarti bahwa kepuasan pelanggan berpengaruh tidak nyata terhadap loyalitas pelanggan.Kepercayaan pelanggan berpengaruh negatif dan tidak signifikan terhadap loyalitas pelanggan bahwa kepercayaan pelanggan berpengaruh tidak nyata terhadap loyalitas pelanggan.Kepuasan dan kepercayaan pelanggan tidak memediasi pengaruh kualitas layanan terhadap loyalitas pelanggan travel agent di kabupaten Badung, 
Jurnal Satyagraha, Vol. 02, No. 02, Agustus 2019 - Januari 2020 ISSN :2620-6358

hal ini berarti bahwa kepuasan dan kepercayaan pelanggan tidak mampu menjelaskan pengaruh kualitas layanan terhadap loyalitas pelanggan.

\section{G. SARAN}

Beberapa saran yang bisa diberikan kepada manajemen travel agent di kabupaten Badung adalah memperhatikan dan meningkatkan kualitas layanan yang diberikan pada aspek tangible (bukti fisik), dengan menata kembali desain interior sehingga kelihatan lebih menarik, serta penampilan staf dapat ditingkatkan dengan memberikan pakaian seragam dengan warna yang cerah serta staf perempuan pada frontliner diwajibkan memakai make up. Peningkatan kepuasan pelanggan dapat dilakukan dengan memberikan pelatihan kepada karyawan secara intensif dan berkelanjutan serta memberikan motivasi baik material (gaji, bonus, insentif) dan non material (penghargaan, promosi) sehingga kinerja karyawan semakin meningkat dan dapat memberikan kualitas layanan prima sehingga pelanggan dapat merasakan kepuasan terhadap kualitas layanan yang diberikan. Kepercayaan pelanggan ditingkatkan dengan beritikad baik untuk menjalin hubungan dengan pelanggan dengan cara memberikan berbagai informasi yang berkaitan dengan perjalanan wisata sesuai dengan permintaan pelanggan tanpa menutup-nutupi ataupun membohongi pelanggan. Peningkatan loyalitas pelanggan dapat dilakukan dengan menawarkan paket-paket wisata yang menarik dengan harga terjangkau, serta dengan memberikan potongan harga pada layanan tertentu sehingga mampu menciptakan pelanggan yang loyal untuk menggunakan kembali jasa travel agent kedepannya dan merekomendasikan kepada orang lain sehingga travel agent mampu bertahan ditengah gempuran travel online. Penelitian selanjutnya diharapkan meneliti kembali kepuasan, kepercayaan dan loyalitas pelanggan dengan variabel moderasi faktor demografi dan switching cost yang diduga kuat dalam memperkuat atau memperlemah pengaruh kepuasan dan kepercayaan pelanggan terhadap loyalitas pelanggan.

\section{DAFTAR PUSTAKA}

Andleeb,N. 2017. The Impact of Trust, Communication, Commitment, And Conflict Handling on Customer Loyalty: An Empirical Evidence from Banks in Lahore, Pakistan. Arabian Journal of Business and Management Review (Kuwait Chapter)

Chodzaza,G.E. dan Gombachika,H.S.H. 2013. Service quality, customer satisfaction and loyalty among industrial customers of a public electricity utility in Malawi. International Journal of Energy Sector Management Vol. 7 No. 2, 2013 pp. 269-282

Chotivanich,P. 2014. Service Quality, Satifaction, And Customer Loyalty In A Full-Service Domestic Airline In Thailand.International Journal of Arts \& Sciences, CD-ROM. ISSN: 1944-6934:: 07(03):161-169 (2014)

Darwin,S. dan Kunto,Y.S. 2014. Analisis Pengaruh Kualitas Layanan Terhadap Loyalitas Pelanggan Dengan Kepuasan Dan Kepercayaan Pelanggan Sebagai Variabel Intervening Pada Asuransi Jiwa Manulife Indonesia - 
Jurnal Satyagraha, Vol. 02, No. 02, Agustus 2019 - Januari 2020 ISSN :2620-6358

Surabaya.Jurnal Manajemen

Pemasaran Petra, Vol 2, No.1 (2014)

Hussein,H.S. dan Hapsari,R. 2015. Customers' Perceptions Of Service Quality Dimensions In The Indonesian Banking Industry: An Empirical Study. Journal of Indonesian Economy and Business Volume 30, Number 1, 2015, $17-29$

Ilyas,A., Arshed,N., Hussain,T. 2016. Service Quality and customer satisfaction: a study on islamic Banks of Pakistan. Journal of Business Strategies, Vol.10, No.1, 2016, pp 73-88

Indiani, N.L.P., Suyatna,I.P.N.Y., Sitiari,N.W. 2016. Peran Kualitas Layanan Dan Kualitas Produk Dalam Meningkatkan Kepuasan dan Loyalitas Nasabah.Jurnal Ekonomi \& Bisnis,Vol. 3, No 2. September 2016, Hal 85-95

Ismail,R. 2014. Pengaruh Kualitas Layanan,

Kualitas Produk dan Kepuasan Nasabah Sebagai Prediktor Dalam Meningkatkan Loyalitas Nasabah. Jurnal Organisasi dan Manajemen, Volume 10, Nomor 2, September 2014, 179-196

Kartikasari,D., Dewanto,A., Rochman,F. 2014. Pengaruh Kualitas Layanan terhadap Kepuasan dan Kepercayaan di Rumah Sakit Bunda Kandangan Surabaya. Jurnal Aplikasi Manajemen (JAM) Vol 12 No 3, 2014

Laely,N. 2016. Analisis Pengaruh Kepercayaan dan Harga Terhadap Loyalitas Pelanggan Dimediasi Kepuasan Pada PT. Telkomsel di
Kota Kediri. Jurnal Ilmu Ekonomi \& Manajemen September 2016, Vol. 3 No.2. hal. $61-74$

Lai,C.S. dan Nguyen,M.C. 2017. Factors Affecting Service Quality, Customer Satisfaction And Loyalty Of Mobile Phone Service Providers In Vietnam. The International Journal of Organizational Innovation Vol 10 Num 2 October 2017

Nunnally,J.C. 1969. Pschycometric Theory, Second Edition, New York : McGraw-Hill Book.

Osarenkhoe,A., $\quad$ Komunda,M.B., Byarugaba,J.M. 2017. Service Quality as a Mediator of Customer Complaint Behaviour and Customer Loyalty. International Review of Management and Marketing | Vol 7. Issue 1. 2017198

Rat,A.H., Salmia,LA.ST., Hutabarat,J. 2015. Pengaruh Kualitas Layanan, Kepuasan dan Kepercayaan Terhadap Loyalitas Pelanggan Kereta Api Eksekutif DAOP 8 Surabaya.Jurnal Teknologi dan Manajemen Industri, Vol. 1 No. 2,

Rifai,M., Adam,R.P. dan Ponirin. 2016. Pengaruh Kualitas Layanan Terhadap Nilai Pelanggan Dan Kepuasan Pelanggan Rental Mobil Fany Di Kota Palu. Jurnal Katalogis, Volume 4 Nomor 5, Mei 2016 hlm 173-185

Setyaningsih,O. 2014. Pengaruh Persepsi Kualitas Pelayanan E-Commerce Terhadap Kepuasan Pelanggan, Kepercayaan Dan Loyalitas Pada Produk Fashion. Jurnal Bisnis \& 
Jurnal Satyagraha, Vol. 02, No. 02, Agustus 2019 - Januari 2020 ISSN :2620-6358

Manajemen Vol. 14, No. 2, 2014 : 67 $-80$

Soegoto,A.S. 2013. Persepsi Nilai Dan Kepercayaan Terhadap Kepuasan

Dan Dampaknya Terhadap Loyalitas Konsumen. Jurnal EMBA. Vol.1 No.3 September 2013, Hal. 1271-1283

Sumertana,I.W. 2016. Pengaruh Kualitas Pelayanan Terhadap Loyalitas Pelanggan Dengan Kepuasan Pelanggan Sebagai Variabel Intervening Pada Water Park Seririt Singaraja Tahun 2014-2015. Jurnal Program Studi Pendidikan Ekonomi (JPPE) Volume: 7 Nomor: 2 Tahun: 2016

Sutrisno, Brahmasari,I.A. dan Panjaitan,H. 2016. The Influence of Service Quality, and Customer Relationship Management (CRM) Of Patient Satisfaction, Brand Image, Trust, and Patient Loyalty on Indonesian National Army Level II Hospitals. International Journal of Business and Management Invention ISSN (Online): 2319-8028, ISSN (Print): $2319-801 X$ www.ijbmi.org || Volume 5 Issue 5 || May. 2016 || PP-30-44

Verma,Y. dan Singh,M.R.P. 2017. Marketing Mix, Customer Satisfaction And Loyalty: An Empirical Study Of Telecom Sector In Bhutan. Indian Journal of Commerce \& Management Studies ISSN: 22490310 EISSN: 2229-5674

Wendha,A.A.A.A.P.,Rahyuda,I.K., Suasana,I.G.A.K. 2013. Pengaruh Kualitas Layanan Terhadap Kepuasan Dan Loyalitas Pelanggan
Garuda Indonesia Di Denpasar. Jurnal Manajemen, Strategi Bisnis, dan Kewirausahaan Vol. 7, No. 1, Februari 2013 